\title{
Immunohistochemical profile and prognostic significance in primary central nervous system lymphoma: Analysis of 89 cases
}

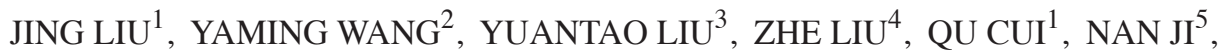 \\ SHENGJUN SUN ${ }^{6}$, BINGXU WANG ${ }^{7}$, YAJIE WANG ${ }^{8}$, XUEFEI SUN ${ }^{1}$ and YUANBO LIU ${ }^{1}$
}

${ }^{1}$ Department of Hematology, Beijing Tiantan Hospital, Capital Medical University; ${ }^{2}$ Department of Neurosurgery, Navy General Hospital, Beijing 100050; ${ }^{3}$ Department of Endocrinology, Qingdao Municipal Hospital Group, Qingdao, Shandong 266011, P.R. China; ${ }^{4}$ Duke University Hospital, Durham, NC 27710, USA; ${ }^{5}$ Department of Neurosurgery;

${ }^{6}$ Neuroimaging Center, Beijing Tiantan Hospital, Capital Medical University, Beijing 100050; ${ }^{7}$ Department of Neurology, Central Hospital of Qilu Petrochemical Hospital Group, Zibo, Shandong $255400 ;{ }^{8}$ Core Laboratory for

Clinical Medical Research, Beijing Tiantan Hospital, Capital Medical University, Beijing 100050, P.R. China

Received January 10, 2016; Accepted July 5, 2017

DOI: $10.3892 / 01.2017 .6893$

\begin{abstract}
The majority of primary central nervous system lymphomas (PCNSLs) are diffuse large B cell lymphoma, characterized by poor prognosis. In the present study, the expression of cluster of differentiation (CD)10, B cell lymphoma (BCL)-6, multiple myeloma-1 (MUM-1), BCL-2, CD138 and Ki-67 was analyzed by immunohistochemistry in 89 Chinese PCNSL cases, and the potential prognostic significance was evaluated. CD10, BCL-6, MUM-1, BCL-2 and CD138 were positive in 16.9 (15/89), 51.7 (46/89), 92.1 (82/89), $73.3(63 / 86)$ and $0 \%(0 / 65)$ of all cases, respectively. According to the Hans algorithm, 71 patients (79.8\%) were classified into the non-germinal center B cell-like (non-GCB) group, indicating a post-germinal center origin of PCNSL. The median follow-up time of 73 patients was 13 months [95\% confidence interval (CI), 10.93-15.08]. The median overall survival (OS) time was 45.3 months (95\% CI, 25.01-65.59) and the median progression-free survival (PFS) time was 30.0 months (95\% CI, 13.43-46.57). Age (>60 years) was associated with a shorter OS time $(\mathrm{P}=0.009)$. Ki-67 (cutoff point $90 \%)$ was associated with shorter OS $(\mathrm{P}=0.037)$ and shorter PFS $(\mathrm{P}=0.039)$ times. No other immunohistochemical markers were associated with prognosis. On multivariate analysis, age (>60 years) was associated with shorter OS time $(\mathrm{P}=0.038)$, but immunophenotype and expression status of $\mathrm{Ki}-67, \mathrm{CD} 10$,
\end{abstract}

Correspondence to: Dr Yuanbo Liu or Dr Xuefei Sun, Department of Hematology, Beijing Tiantan Hospital, Capital Medical University, 6 Tiantan Xili, Dongcheng, Beijing 100050, P.R. China

E-mail: yuanbol@ccmu.edu.cn

E-mail: sunxuefei@sina.com

Key words: primary central nervous system lymphoma, diffuse large B cell lymphoma, germinal center B cell-like, non-germinal center B cell-like, Ki-67
BCL-6 and BCL-2 did not predict prognosis. In conclusion, high $\mathrm{Ki}-67$ expression may predict poor prognosis in PCNSL. The present study was limited by its sample size and short follow-up time. This requires more evidence to further clinical study.

\section{Introduction}

Primary central nervous system lymphoma (PCNSL) is an aggressive neoplasm of the central nervous system with poor prognosis, accounting for $2-3 \%$ of all brain tumors worldwide $(1,2)$. The incidence of PCNSL has increased markedly in immunocompetent patients for unknown reasons over the previous decades, whereas the incidence of human immunodeficiency virus (HIV)-associated PCNSLs has declined, possibly due to the development of highly active antiretroviral therapies $(3,4)$. Morphologically, $~ 95 \%$ of these tumors are diffuse large B cell lymphoma (DLBCL), according to the new World Health Organization classification (5). Although the prognosis of PCNSL has been improved by optimal systemic treatment based on high-dose methotrexate (HD-MTX) (6-8), the overall survival (OS) of the majority of patients remains poor. This underlines the need to identify prognostic biomarkers for potential therapeutic targets and risk-stratified treatment.

In systemic DLBCL, based on cDNA microarray and immunohistochemical staining with various markers, including cluster of differentiation (CD)10, B cell lymphoma (BCL)-6 and multiple myeloma-1/interferon regulatory factor-4 (MUM-1), previous studies have identified two subtypes of DLBCL by Hans algorithm, namely, germinal center (GC) B cell-like (GCB) and non-GCB (9-13). Patients in the GCB subgroup showed an improved prognosis compared with $\mathrm{ABC}$ (activated B cell-like; including activated GCB and activated non-GCB, according to Chang's classification) $(9,10,12,13)$. In PCNSL, numerous studies have been performed to observe the prognostic significance of the variable biological markers widely used in systemic DLBCL (14-24). The present study aimed to analyze the expression profile of immunohistochemical 
markers and their potential prognostic significance in 89 Chinese PCNSL cases.

\section{Materials and methods}

Patients and tumor specimens. The clinical data of 89 immunocompetent patients with PCNSL were retrospectively reviewed at the Department of Hematology, Beijing Tiantan Hospital, Capital Medical University (Beijing, China) and the Department of Neurosurgery, Navy General Hospital (Beijing, China), between July 2009 and April 2015. Of the total 89 patients, 53 were male and 36 were female (male-female sex ratio of 1.47:1). The median age was 56 years (range, $11-85$ years; $\leq 60$ years, 54 patients; $>60$ years, 35 patients). All specimens were obtained by stereotactic biopsy or surgery for pathological diagnosis prior to treatment. Diagnosis of DLBCL was made by histological review of all specimens by two pathologists using light microscopy. The pathologists assessed the immunohistochemical markers including CD20, CD10, BCL-6, BCL-2, MUM1, CD138 and Ki-67 independently and between 15 and 20 fields were analyzed/specimen (magnification, $\mathrm{x} 400$ ). A total of $16 / 89$ patients were lost to follow-up. In the follow-up of the remaining 73 patients, 39 received HD-MTX plus cytarabine $\left[3.5 \mathrm{~g} / \mathrm{m}^{2}\right.$ intravenous (i.v.) in $3 \mathrm{~h}$ on day $1+0.5-1 \mathrm{~g} / \mathrm{m}^{2}$ i.v. on day 2 according to age and Karnofsky Performance Status] every 3 weeks, and the other patients received HD-MTX plus tomozolomide $\left(3.5 \mathrm{~g} / \mathrm{m}^{2}\right.$ i.v. in $3 \mathrm{~h}$ on day $1+100 \mathrm{mg} / \mathrm{m}^{2}$ administered orally on days $1-5)$ every 3 weeks.

The present study protocol was approved by the Ethics Committees of Beijing Tiantan Hospital and Navy General Hospital. All patients gave written informed consent.

Immunohistochemical analysis. Tumor specimens were fixed with $10 \%$ formalin at room temperature for $24 \mathrm{~h}$ and paraffin-embedded. A series of $4-\mu \mathrm{m}$ sections were obtained for conventional hematoxylin and eosin (H\&E) and immunohistochemical staining. Sections were deparaffinized in xylene and dehydrated with ethanol. Endogenous peroxidase was blocked with $0.1 \%$ hydrogen peroxide-methanol for $30 \mathrm{~min}$ at room temperature. Sections were washed with PBS, and the specimens were then incubated for antigen retrieval in a microwave oven for $15 \mathrm{~min}$, followed by washing with PBS. The sections were treated with $3 \% \mathrm{H}_{2} \mathrm{O}_{2}$ for 5 min at room temperature to block endogenous peroxidase activity, and sections were then incubated with the working dilution of each monoclonal antibody in a moist box (100\% humidity) at $4^{\circ} \mathrm{C}$ overnight. Monoclonal antibodies against CD20 (UM800002, 1:100 dilution), CD10 (UM870127, 1:600 dilution), BCL-6 (TA804186, 1:150 dilution), MUM1 (TA327705; 1:100-1:500 dilution), BCL-2 (UM870117, 1:500 dilution), Ki-67 (TA352729, 1:100), CD138 (TA327619, 1:25-1:200) were used and all purchased from OriGene Technologies, Inc. (Rockville, MD, USA). Subsequent to washing the specimens with PBS, they were incubated with corresponding secondary antibodies at a dilution of 1:2,000 [horseradish peroxidase-conjugated monoclonal goat anti-mouse IgG (HS201-01) or horseradish peroxidase-conjugated monoclonal goat anti-rabbit IgG (HS101-01); TransGen Biotech Co., Ltd., Beijing, China] for $1 \mathrm{~h}$ at room temperature. The EnVision kit was purchased from OriGene Technologies, Inc., and immunohistochemistry (EnVision method) was performed according to the manufacturer's protocol. Systemic DLBCLs were used as positive controls.

The staining for each marker was scored by two pathologists independently. Images were captured using a LEITZ DMR microscope (between 15 and 20 fields; magnification, x400; Leica Microsystems GmbH, Wetzlar, Germany). Staining was considered positive for CD10, BCL-6, MUM-1 and CD138 when $>30 \%$ of cells were positively stained (25). For BCL-2, staining was considered positive when $>50 \%$ of cells were positively stained (26) (between 15 and 20 fields; magnification, $\mathrm{x} 400$ ). Ki-67 expression was evaluated by semi-quantitative method and on the basis of the proportion of positive tumor cells (between 0 and 100\%). High expression was considered when $>90 \%$ of cells were positively stained for Ki-67. Low expression was considered when $\leq 90 \%$ of cells were positively stained for Ki-67.

\section{Immunophenotype classification}

Hans' method. Using a decision tree, Hans et al (12) divided tumors into two main subgroups according to three markers: CD10, BCL-6 and MUM-1. All CD10 ${ }^{+}$tumors and those with a CD10- $\mathrm{BCL}-6^{+} \mathrm{MUM}^{-}{ }^{-}$phenotype were considered as the GCB subgroup. The non-GCB subgroup included CD10 $0^{-}$BCL- $6^{+}$MUM-1 $1^{+}$, CD10 BCL-6- ${ }^{-}{ }^{-}$M $-1^{+}$and CD10 BCL-6- MUM-1-immunophenotypes.

Chang's method. Using the immunohistochemical markers CD10 and BCL- 6 for GCB markers, and MUM- 1 and CD138 for $\mathrm{ABC}$ markers, Chang et al (13) classified the tumors as GCB and activated GBC subgroups (activated GCB and activated non-GCB subgroups). At least one positive GCB marker without the expression of activation markers was considered as the GCB subgroup. The activated GCB subgroup expressed CD10 and/or BCL- 6 and one activation marker. The activated non-GCB subgroup expressed at least one activation marker without the expression of GCB markers.

Statistical analysis. OS time was counted from the start of treatment to the time of mortality due to any cause. Progression-free survival (PFS) time was counted from the start of treatment to the time of disease progression or mortality due to PCNSL. Kaplan-Meier survival curves were obtained, and differences in OS or PFS times were performed using the log-rank test. Multivariate analysis for OS and PFS times using the Cox proportional hazards regression models. Distribution of the characteristics of patients examined using the $\chi^{2}$ test. All statistical analyses were performed using SPSS 17.0 (SPSS, Inc., Chicago, IL, USA). $\mathrm{P}<0.05$ was considered to indicate a statistically significant difference.

\section{Results}

Characteristics and clinical outcomes of patients. The characteristics of patients with PCNSL are described in Table I. All patients with PCNSL were immunocompetent patients who were HIV-negative. Of the total 89 patients, 53 were male and 36 were female (male-female sex ratio of 1.47:1). The median age was 56 years (range, 11-85 years; $\leq 60$ years, 54 patients; 
Table I. Clinical characteristics of patients with PCNSL.

\begin{tabular}{|c|c|}
\hline Characteristics & Patients \\
\hline Median age (range) & $56(11-85)$ \\
\hline \multicolumn{2}{|l|}{ Age, n $(\%)$, years } \\
\hline$>60$ & $35 / 89$ \\
\hline$\leq 60$ & $54 / 89$ \\
\hline \multicolumn{2}{|l|}{ Sex, n (\%) } \\
\hline Male & $53 / 89(59.6)$ \\
\hline Female & $36 / 89(40.4)$ \\
\hline \multicolumn{2}{|l|}{ ECOG, n (\%) } \\
\hline $0-1$ & 21/89 (23.6) \\
\hline $2-4$ & $68 / 89(76.4)$ \\
\hline \multicolumn{2}{|l|}{$\mathrm{LDH}, \mathrm{n}(\%)$} \\
\hline Elevated & $30 / 76(39.5)$ \\
\hline Normal & $46 / 76(60.5)$ \\
\hline \multicolumn{2}{|l|}{ No. of lesions, n (\%) } \\
\hline 1 & 29/89 (32.6) \\
\hline$\geq 2$ & $60 / 89(67.4)$ \\
\hline \multicolumn{2}{|l|}{ Deep brain lesions, n (\%) } \\
\hline Absent & 28/89 (31.5) \\
\hline Present & $61 / 89(68.5)$ \\
\hline \multicolumn{2}{|l|}{ Chemotherapy, n (\%) } \\
\hline HD-MTX+Ara-C & $39 / 73(53.4)$ \\
\hline HD-MTX+TMZ & $34 / 73(46.6)$ \\
\hline Median OS (95\% CI) & $45.3(25.01-65.59)$ \\
\hline Median PFS (95\% CI) & $30.0(13.43-46.57)$ \\
\hline \multicolumn{2}{|c|}{$\begin{array}{l}\text { ECOG, Eastern Cooperative Oncology Group; LDH, lactate dehy- } \\
\text { drogenase; HD-MTX + Ara-C, high-dose methotrexate + cytarabine; } \\
\text { HD-MTX + TMZ, high-dose methotrexate + tomozolomide; OS, } \\
\text { overall survival; PFS, progression-free survival; CI, confidence } \\
\text { interval. }\end{array}$} \\
\hline
\end{tabular}

$>60$ years, 35 patients). In total, 21 patients (23.6\%) had an Eastern Cooperative Oncology Group (ECOG) performance status (27) of 0 or 1 and 68 patients (76.4\%) had an ECOG performance status of 2-4. Multiple brain lesions were observed in $67.4 \%(60 / 89)$ of patients and the presence of deep brain structures was observed in $68.5 \%(61 / 89)$ of patients. The concentration of serum lactate dehydrogenase (LDH) was elevated in $30(39.5 \%)$ of 76 patients.

Follow-up was performed for 73 patients, as 16 were lost to follow-up. The median follow-up time was 13 months [95\% confidence interval (CI), 10.93-15.08]. The median OS time was 45.3 months (95\% CI, 25.01-65.59) and the median PFS time was 30.0 months (95\% CI, 13.43-46.57).

Cytological and immunohistochemical analysis. In tumor cells with a diffuse distribution, the nuclei were 2 times greater than normal lymphocytes. CD20 staining showed diffuse patterns; CD20, CD10 and CD138 showed cell membrane staining; BCL-6, MUM-1 and Ki-67 showed nuclei staining; and BCL-2 showed cytoplasmic staining of cells (Fig. 1).
CD10, BCL-6, and MUM-1 were positive in 16.9 (15/89), $51.7(46 / 89)$ and $92.1 \%(82 / 89)$ of patients. Among 86 tested samples, BCL-2 was positive in $73.3 \%$ (63/86). In total, 42 PCNSLs showed $>90 \% \mathrm{Ki}-67$ expression. CD138 was negative in $100 \%(65 / 65)$.

Immunophenotype classification. According to the Hans classification, 18 tumors $(20.2 \%)$ were classified in the GCB subgroup: 8 (9.0\%) were $\mathrm{CD} 10^{+} \mathrm{BCL}-6^{+} \mathrm{MUM}^{+}{ }^{+} ; 2$ (2.2\%) were $\mathrm{CD} 10^{+} \mathrm{BCL}^{-}{ }^{+} \mathrm{MUM}^{-} ; 5$ (5.6\%) were CD10 ${ }^{+} \mathrm{BCL}-6$ MUM-1+; 3 (3.4\%) were CD10- ${ }^{-}$BCL-6 ${ }^{+}$MUM-1'; and none were $\mathrm{CD}^{-} 0^{+} \mathrm{BCL}^{-} 6^{-} \mathrm{MUM}^{-}$. A total of 71 tumors $(79.8 \%)$ were considered as non-GCB: $33(37.1 \%)$ were $\mathrm{CD} 10^{-} \mathrm{BCL}^{-} 6^{+}$ MUM-1+; 36 (40.5\%) were MUM-1+ only; and 2 (2.2\%) were negative for all markers tested.

According to the Chang classification, the 87 patients were classified into the three subgroups: 5 (5.7\%) tumors were $\mathrm{CD}_{10}{ }^{+} \mathrm{BCL}_{-} 6^{+-} \mathrm{MUM}^{-}{ }^{-}$and CD10- ${ }^{-} \mathrm{BCL}-6^{+} \mathrm{MUM}^{-}{ }^{-}$, and were classified as $\mathrm{GCB} ; 46(52.9 \%)$ tumors were $\mathrm{CD} 10^{+}$

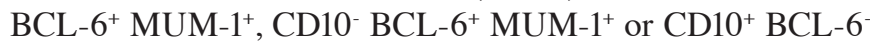
MUM-1 ${ }^{+}$and were classified as activated GCB; and 36 (41.4\%) tumors were $\mathrm{CD} 10^{-} \mathrm{BCL}-6^{-} \mathrm{MUM}-1^{+}$and were classified as activated non-GCB.

Analysis of prognosis. Among the clinical characteristics of patients, an age $>60$ years was associated with a shorter OS time compared with an age of $\leq 60$ years (univariate analysis, $\mathrm{P}=0.009$; multivariate analysis, hazard ratio $=0.229 ; 95 \% \mathrm{CI}$, 0.057-0.922; $\mathrm{P}=0.038$; Fig. 2). Among the biological markers, based on univariate analysis, Ki-67 expression (>90\%) was associated with a shorter $\mathrm{OS}(\mathrm{P}=0.037)$ and shorter PFS ( $\mathrm{P}=0.039)$ times, compared with $\leq 90 \%$ Ki-67 expression (Fig. 3). However, on multivariate analysis, no biological markers were associated with OS and PFS time. No significant prognostic effect on OS or PFS was observed for the other clinical or biological parameters (sex, ECOG, CD10, BCL-6, BCL-2, LDH concentration, number of lesions, chemotherapy regimens and GCB/non-GCB subgroups) (Table II).

\section{Discussion}

In the present study, it was revealed that, unlike systemic DLBCLs, the majority of PCNSLs originate from post-GC, with a low expression of the GC marker CD10, expression of the GC marker BCL-6 and high expression of the activated B cell-like marker MUM-1, which is consistent with the majority of previous studies $(14-24,28,29)$ (Table III). In addition, the co-expression of BCL-6 and MUM-1 and the absence of late post-GC marker CD138 expression indicated the activated immunophenotype and the early post-GC origin of PCNSL, which was in accordance with Camilleri-Broët et al (24).

A number of previous studies $(21,23,24,28-30)$ have utilized immunohistochemical markers to predict the prognosis of PCNSL. However, the significance of immunohistochemical markers on the prognosis of PCNSL remains questionable due to limitations, including a small sample size, heterogeneous treatment regimens or different methods and standards of immunohistochemistry. The present study analyzed the expression of biological markers and evaluated their prognostic significance in the largest retrospective studies 
A

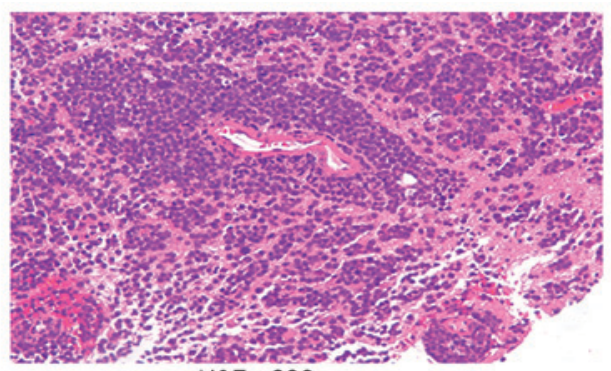

c

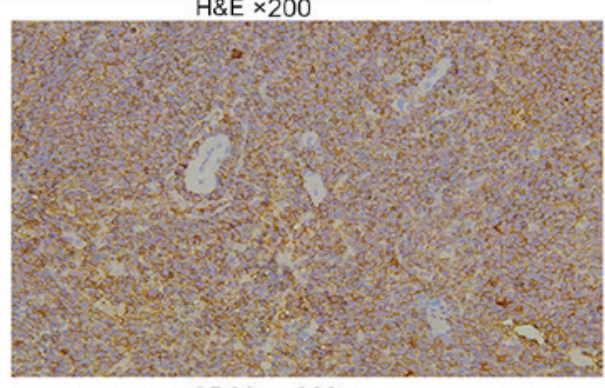

$\mathrm{CD} 20+\times 200$

E

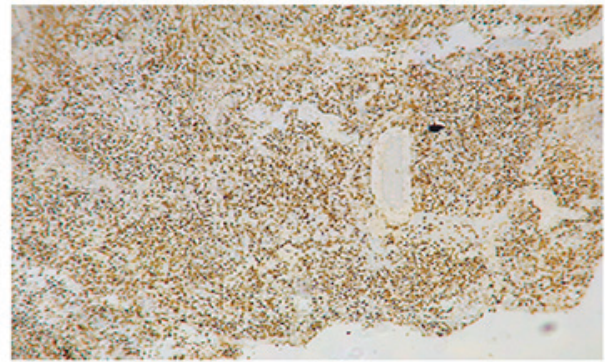

G

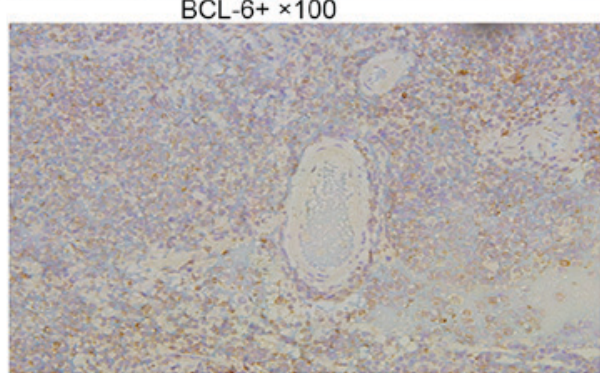

$\mathrm{BCL}-2+\times 200$

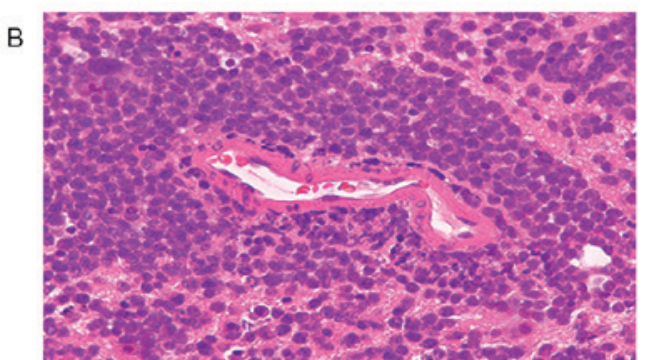

$\mathrm{H} \& \mathrm{E} \times 400$

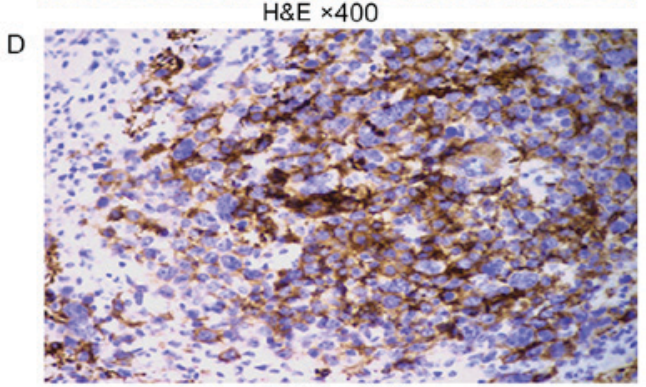

CD10 $+\times 200$

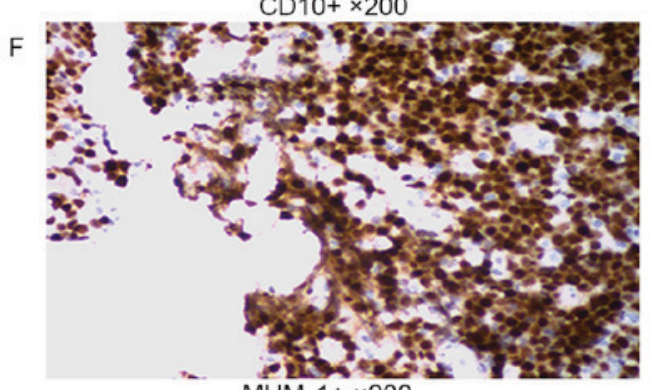

MUM- $1+\times 200$

$\mathrm{H}$

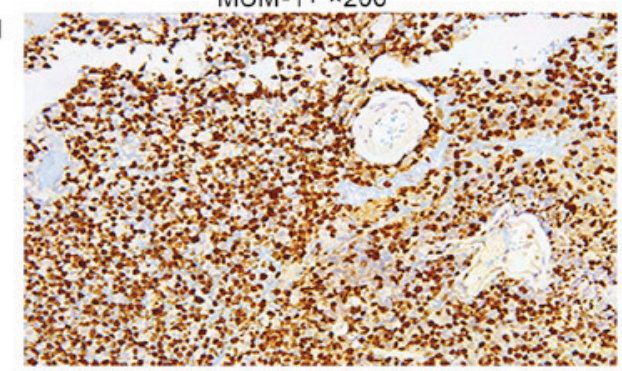

Ki $-67+\times 200$

Figure 1. Immunohistochemical labeling. (A and B) H\&E staining. In tumor cells with the diffuse distribution, the size of nuclei were 2 times greater than of normal lymphocytes. (A) Magnification, x200. (B) Magnification, x400. (C) CD20 cell membrane staining performed using the EnVision method Magnification, x200. (D) CD10 cell membrane staining performed using the EnVision method. Magnification, x200. (E) BCL-6, nuclei staining, EnVision method, x100. (F) MUM-1 nuclei staining performed using the EnVision method. Magnification, x200. (G) BCL-2 cytoplasmic staining performed using the EnVision method. Magnification, x200. (H) Ki-67 nuclei staining performed using the EnVision method. Magnification, x200. H\&E, hematoxylin and eosin; $\mathrm{CD}$, cluster of differentiation; BCL, B cell lymphoma; MUM-1, multiple myeloma-1.
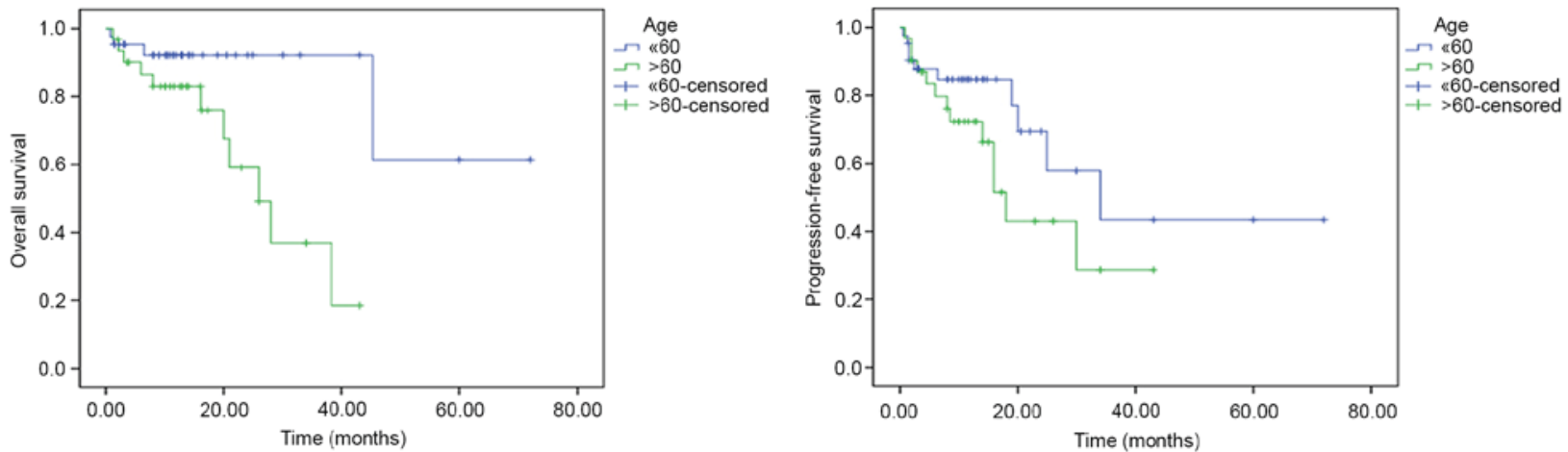

Figure 2. Comparison of OS and PFS time between age $>60$ and age $\leq 60$ years by log-rank test. Univariate analysis revealed that younger age ( $\leq 60$ years) was associated with a longer OS time ( $\mathrm{P}=0.009)$ compared with older age ( $>60$ years). No significant difference was observed for $\mathrm{PFS}$ time ( $\mathrm{P}=0.141)$. OS, overall survival; PFS, progression-free survival. 
Table II. Univariate and multivariate analyses for overall survival and progression-free survival.

A, Overall survival

\begin{tabular}{|c|c|c|c|c|}
\hline \multirow[b]{2}{*}{ Characteristic } & \multirow{2}{*}{$\begin{array}{c}\begin{array}{c}\text { Univariate analysis } \\
\text { (log-rank test) }\end{array} \\
\text { P-value }\end{array}$} & \multicolumn{3}{|c|}{ Multivariate analysis (Cox test) } \\
\hline & & HR & P-value & $95 \% \mathrm{CI}$ \\
\hline Age ( $\leq 60$ vs. $>60$ years $)$ & 0.009 & 0.229 & 0.038 & $0.057-0.922$ \\
\hline Sex (male vs. female) & 0.525 & - & - & - \\
\hline ECOG (0-1 vs. 2-4) & 0.377 & - & - & - \\
\hline CD10 (positive vs. negative) & 0.924 & - & - & - \\
\hline BCL-6 (positive vs. negative) & 0.453 & 0.612 & 0.468 & $0.163-2.303$ \\
\hline BCL-2 (positive vs. negative) & 0.328 & 0.549 & 0.427 & $0.125-2.409$ \\
\hline Ki-67 (>90 vs. $\leq 90 \%)$ & 0.037 & 0.414 & 0.162 & $0.120-1.424$ \\
\hline Immunophenotype (GCB vs. non-GCB) & 0.410 & 0.506 & 0.365 & $0.116-2.209$ \\
\hline Chemotherapy (HD-MTX+Ara-C vs. HD-MTX+TMZ) & 0.671 & 0.993 & 0.990 & $0.309-3.191$ \\
\hline LDH (elevated vs. normal) & 0.442 & - & - & - \\
\hline No. of lesions (1 vs. $\geq 2)$ & 0.592 & 0.880 & 0.835 & $0.262-2.954$ \\
\hline
\end{tabular}

B, Progression-free survival

\begin{tabular}{|c|c|c|c|c|}
\hline \multirow[b]{2}{*}{ Characteristic } & \multirow{2}{*}{$\begin{array}{c}\begin{array}{c}\text { Univariate analysis } \\
\text { (log-rank test) }\end{array} \\
\text { P-value }\end{array}$} & \multicolumn{3}{|c|}{ Multivariate analysis (Cox test) } \\
\hline & & HR & P-value & $95 \% \mathrm{CI}$ \\
\hline Age ( $\leq 60$ vs. $>60$ years $)$ & 0.141 & 0.566 & 0.237 & $0.220-1.456$ \\
\hline Sex (male vs. female) & 0.957 & - & - & - \\
\hline ECOG (0-1 vs. 2-4) & 0.313 & - & - & - \\
\hline CD10 (positive vs. negative) & 0.264 & - & - & - \\
\hline BCL-6 (positive vs. negative) & 0.304 & 0.736 & 0.571 & $0.255-2.126$ \\
\hline BCL-2 (positive vs. negative) & 0.463 & 0.649 & 0.438 & $0.218-1.934$ \\
\hline Ki-67 (>90 vs. $\leq 90 \%)$ & 0.039 & 0.437 & 0.075 & $0.176-1.086$ \\
\hline Immunophenotype (GCB vs. non-GCB) & 0.131 & 0.398 & 0.109 & $0.129-1.228$ \\
\hline Chemotherapy (HD-MTX+Ara-C vs. HD-MTX+TMZ) & 0.459 & 1.063 & 0.898 & $0.422-2.675$ \\
\hline LDH (elevated vs. normal) & 0.779 & - & - & - \\
\hline No. of lesions (1 vs. $\geq 2$ ) & 0.740 & 1.021 & 0.967 & $0.387-2.696$ \\
\hline
\end{tabular}

ECOG, Eastern Cooperative Oncology Group; LDH, lactate dehydrogenase; HD-MTX + Ara-C, high-dose methotrexate + cytarabine; HD-MTX + TMZ, high-dose methotrexate + tomozolomide; OS, overall survival; PFS, progression-free survival; CI, confidence interval; HR, hazard ratio; CD10, cluster of differentiation 10; BCL, B cell lymphoma.
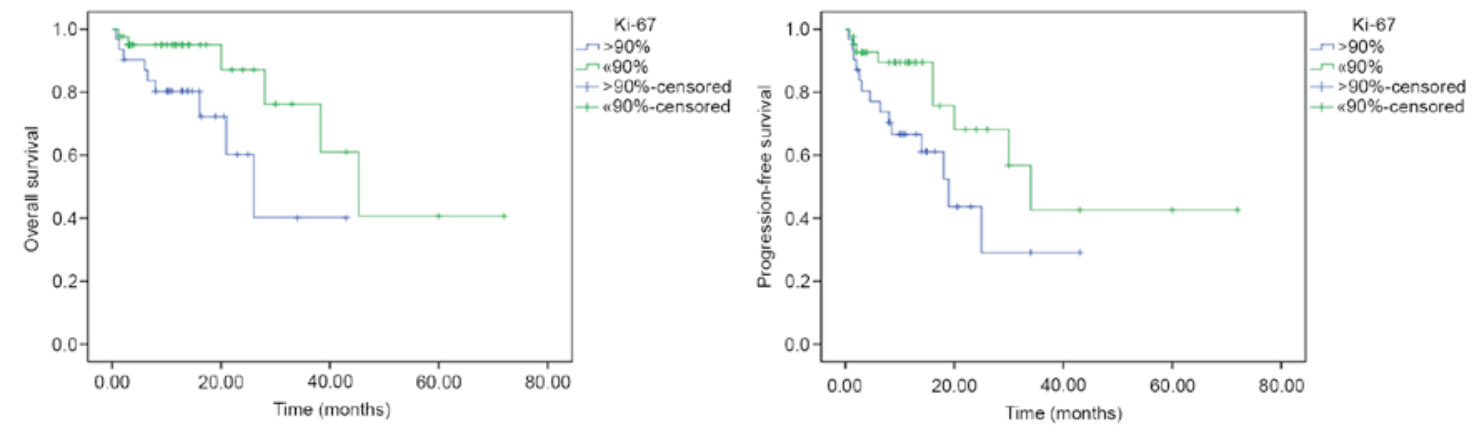

Figure 3. Comparison of OS and PFS time between Ki-67 expression $>90$ and $\leq 90 \%$ by log-rank test. Univariate analysis revealed that high expression of $\mathrm{Ki}-67(>90 \%)$ was associated with a shorter OS $(\mathrm{P}=0.037)$ and $\mathrm{PFS}(\mathrm{P}=0.039)$ times compared with low expression of Ki-67 $(\leq 90 \%)$. OS, overall survival; PFS, progression-free survival. 


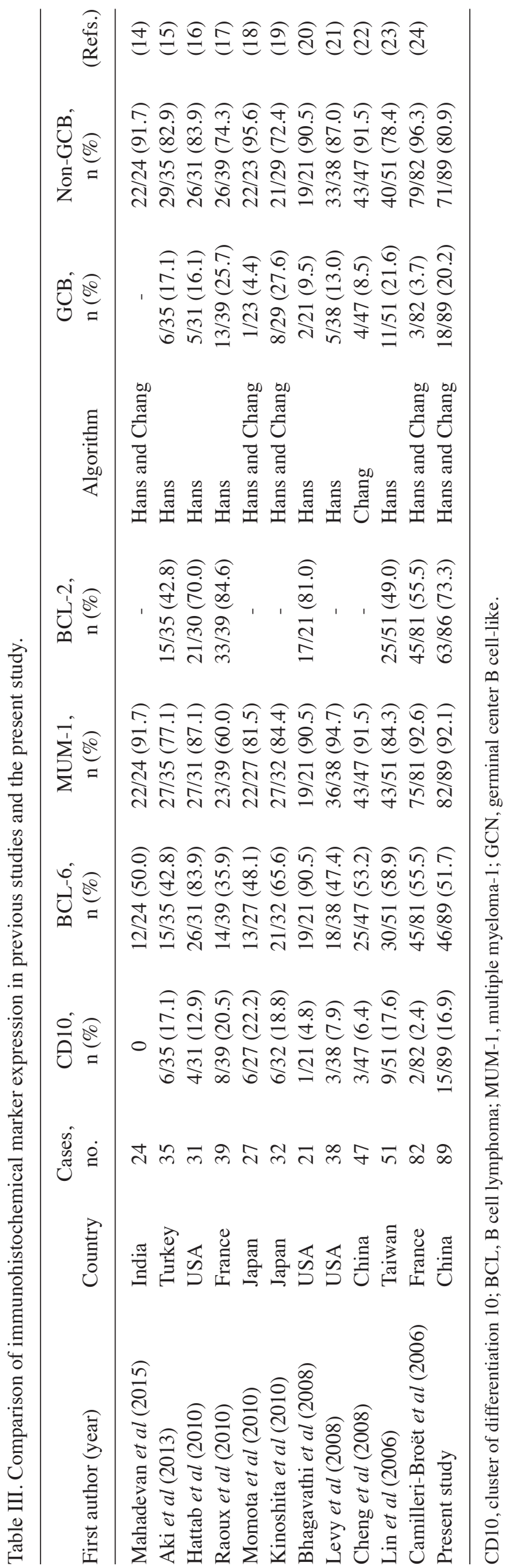

at present. All the patients uniformly received HD-MTX based chemotherapy as the first line of treatment. The Ki-67 proliferative index, a nuclear antigen present in all stages of the cell cycle, with the exception of $\mathrm{G}_{0}$, represents the active growth fraction of the tumor (31-33). Ki-67 is a valuable immunohistochemical marker to distinguish indolent from aggressive lymphomas, particularly in small needle biopsies where exact typing may not be possible (31). Several studies have demonstrated that high expression of Ki-67 is an adverse prognostic marker in systemic DLBCL (34-36). In the present study, it was also observed that $\mathrm{Ki}-67$ expression is a significant prognostic parameter of poor prognosis in patients with PCNSL. Unlike systemic DLBCLs, the mean Ki-67 index for PCNSL was high (mean, 88\%). Patel et al (28) revealed that the proliferative index was high (60-98\%) in their study of 73 PCNSL cases. Hashmi et al (31) showed that the mean Ki-67 index for indolent non-Hodgkin lymphoma (NHL) included $23 \%$ for small cell, $25 \%$ for mantle cell, $28.5 \%$ for marginal zone and $34.6 \%$ for follicular lymphoma. By contrast, the mean Ki-67 index for aggressive lymphomas was 66.4, 66.9, $80.3,83.3$ and $94.4 \%$ for DLBCL, T cell, anaplastic large cell, lymphoblastic and Burkitt's lymphoma, respectively (31). A uniform high expression of $\mathrm{Ki}-67$ is a notable feature of PCNSL, which may explain the poor outcome of PCNSLs. Previous studies did not reveal the prognostic significance of Ki-67, which may be due to the small number of patients with a uniform high expression of Ki-67 or the different immunohistochemical methods used.

CD10 is expressed in pre-B cells and germinal center B cells $(37,38)$. MUM-1 performs an important role in the terminal stages of B cell differentiation and can be used as a post-GC cell or activation marker $(39,40)$. Due to the low expression of CD10 and the high expression of MUM-1, CD10 and MUM-1 where considered to be characteristics of PCNSL, but not prognostic indicators.

BCL-2, a proto-oncogene, localizes to mitochondria and enhances cell survival by blocking programmed cell death (41). BCL-2 protein expression is an important independent predictor of survival in patients with systemic DLBCL $(42,43)$. However, in the present study, no association between BCL-2 and prognosis was observed, which is in accordance with the studies by Krogh-Jensen et al (44) and Preusser et al (45).

The BCL-6 gene encoding a nuclear-located Krüppel-type zinc finger protein is rearranged in $\sim 30 \%$ of DLBCLs and is expressed predominantly in normal GCB cells and associated lymphomas $(46,47)$. BCL-6 may have an important role in regulating the differentiation of normal GCB cells, and its deregulated expression may contribute to lymphomagenesis (30). Previous studies about the prognostic significance of BCL-6 expression remain controversial. Survival analyses revealed BCL-6 expression as an independent prognostic parameter of DLBCL associated with favorable outcomes, and its positivity indicates an improved disease course $(21,29,45)$. The CALGB 50202 study of the prospective G-PCNSL-SG1 trial disclosed that BCL-6 may assume clinical relevance as an unfavorable prognostic biomarker in PCNSL $(7,30)$. In the present study, BCL-6 expression was not associated with OS or PFS. The present study is a retrospective study with a short follow-up time, and these limitations may explain the discrepancy between the present study and previous studies. 
In the present study, no significant difference was observed between GCB and non-GCB subgroups on OS or PFS time, which is in accordance with earlier studies $(12,17,18,24,30)$. These results may indicate that PCNSL has a common immunophenotype classification, but this subtype classification may not have an effect on prognosis.

In conclusion, the present study confirmed the activated immunophenotype and the early post-GC origin of PCNSL, and determined that older age ( $>60$ years) was associated with a shorter OS time. In addition, high Ki-67 expression was found to be a valuable biological marker for poor prognosis. Considering the short follow-up time of the present retrospective study and the controversial results of previous studies, additional prospective studies are required.

\section{Acknowledgements}

The present study was supported by the National Natural Science Foundation of China (grant nos. 81272842 to Y.L. and 81500157 to Q.C.) and the Beijing Natural Science Foundation (grant no. 7172071). The authors thank Dr Young Whang (Lineberger Comprehensive Cancer Center, University of North Carolina, Chapel Hill, NC, USA) for a review of the manuscript before submission.

\section{References}

1. Batchelor T and Loeffler JS: Primary CNS lymphoma. J Clin Oncol 24: 1281-1288, 2006.

2. Abrey LE: Primary central nervous system lymphoma. Curr Opin Neurol 22: 675-680, 2009.

3. Corn BW, Marcus SM, Topham A, Hauck W and Curran WJ Jr: Will primary central nervous system lymphoma be the most frequent brain tumor diagnosed in the year 2000? Cancer 79 2409-2413, 1997.

4. Kadan-Lottick NS, Skluzacek MC and Gurney JG: Decreasing incidence rates of primary central nervous system lymphoma. Cancer 95: 193-202, 2002.

5. Campo E, Swerdlow SH, Harris NL, Pileri S, Stein H and Jaffe ES: The 2008 WHO classification of lymphoid neoplasms and beyond: Evolving concepts and practical applications Blood 117: 5019-5032, 2011.

6. Omuro A, Correa DD, DeAngelis LM, Moskowitz $\mathrm{CH}$, Matasar MJ, Kaley TJ, Gavrilovic IT, Nolan C, Pentsova E, Grommes CC, et al: R-MPV followed by high-dose chemotherapy with TBC and autologous stem-cell transplant for newly diagnosed primary CNS lymphoma. Blood 125: 1403-1410, 2015

7. Rubenstein JL, Hsi ED, Johnson JL, Jung SH, Nakashima MO, Grant B, Cheson BD and Kaplan LD: Intensive chemotherapy and immunotherapy in patients with newly diagnosed primary CNS lymphoma: CALGB 50202 (Alliance 50202). J Clin Oncol 31: 3061-3068, 2013.

8. Liu J, Sun XF, Qian J, Bai XY, Zhu H, Cui QU, Li XY, Chen YD, Wang YM and Liu YB: Immunochemotherapy for primary central nervous system lymphoma with rituximab, methotrexate, cytarabine and dexamethasone: Retrospective analysis of 18 cases. Mol Clin Oncol 3: 949-953, 2015.

9. Alizadeh AA, Eisen MB, Davis RE, Ma C, Lossos IS, Rosenwald A, Boldrick JC, Sabet H, Tran T, Yu X, et al: Distinct types of diffuse large B-cell lymphoma identified by gene expression profiling. Nature 403: 503-511, 2000.

10. Rosenwald A, Wright G, Chan WC, Connors JM, Campo E, Fisher RI, Gascoyne RD, Muller-Hermelink HK, Smeland EB, Giltnane JM, et al: The use of molecular profiling to predict survival after chemotherapy for diffuse large-B-cell lymphoma. N Engl J Med 346: 1937-1947, 2002.

11. Shipp MA, Ross KN, Tamayo P, Weng AP, Kutok JL, Aguiar RC, Gaasenbeek M, Angelo M, Reich M, Pinkus GS, et al: Diffuse large B-cell lymphoma outcome prediction by gene-expression profiling and supervised machine learning. Nat Med 8: 68-74, 2002 .
12. Hans CP, Weisenburger DD, Greiner TC, Gascoyne RD, Delabie J, Ott G, Müller-Hermelink HK, Campo E, Braziel RM, Jaffe ES, et al: Confirmation of the molecular classification of diffuse large B-cell lymphoma by immunohistochemistry using a tissue microarray. Blood 103: 275-282, 2004.

13. Chang CC, McClintock S, Cleveland RP, Trzpuc T, Vesole DH, Logan B, Kajdacsy-Balla A and Perkins SL: Immunohistochemical expression patterns of germinal center and activation B-cell markers correlate with prognosis in diffuse large B-cell lymphoma. Am J Surg Pathol 28: 464-470, 2004.

14. Mahadevan A, Rao CR, Shanmugham M and Shankar SK: Primary central nervous system diffuse large B-cell lymphoma in the immunocompetent: Immunophenotypic subtypes and Epstein-Barr virus association. J Neurosci Rural Pract 6: 8-14, 2015.

15. Aki H, Uzunaslan D, Saygin C, Batur S, Tuzuner N, Kafadar A, Ongoren $\mathrm{S}$ and $\mathrm{Oz} \mathrm{B}$ : Primary central nervous system lymphoma in immunocompetent individuals: A single center experience. Int J Clin Exp Pathol 6: 1068-1075, 2013.

16. Hattab EM, Martin SE, Al-Khatib SM, Kupsky WJ, Vance GH, Stohler RA, Czader M and Al-Abbadi MA: Most primary central nervous system diffuse large B-cell lymphomas occurring in immunocompetent individuals belong to the nongerminal center subtype: A retrospective analysis of 31 cases. Mod Pathol 23: 235-243, 2010.

17. Raoux D, Duband S, Forest F, Trombert B, Chambonnière ML, Dumollard JM, Khaddage A, Gentil-Perret A and Péoc'h M: Primary central nervous system lymphoma: Immunohistochemical profile and prognostic significance. Neuropathology 30: 232-240, 2010.

18. Momota H, Narita Y, Maeshima AM, Miyakita Y, Shinomiya A, Maruyama T, Muragaki Y and Shibui S: Prognostic value of immunohistochemical profile and response to high-dose methotrexate therapy in primary CNS lymphoma. J Neurooncol 98: $341-348,2010$.

19. Kinoshita M, Hashimoto N, Izumoto S, Okita Y, Kagawa N, Maruno M, Ohnishi $\mathrm{T}$, Arita $\mathrm{N}$ and Yoshimine $\mathrm{T}$ : Immunohistological profiling by B-cell differentiation status of primary central nervous system lymphoma treated by high-dose methotrexate chemotherapy. J Neurooncol 99: 95-101, 2010.

20. Bhagavathi S, Sharathkumar A, Hunter S, Sung L, Kanhere R, Venturina MD and Wilson JD: Activated B-cell immunophenotype might be associated with poor prognosis of primary central nervous system lymphomas. Clin Neuropathol 27: 13-20, 2008.

21. Levy O, Deangelis LM, Filippa DA, Panageas KS and Abrey LE: Bcl-6 predicts improved prognosis in primary central nervous system lymphoma. Cancer 112: 151-156, 2008.

22. Cheng J, Tu P, Shi QL, Zhou HB, Zhou ZY, Zhao YC, Ma HH and Zhou XJ: Primary diffuse large B-cell lymphoma of central nervous system belongs to activated B-cell-like subgroup: A study of 47 cases. Zhonghua Bing Li Xue Za Zhi 37: 384-389, 2008 (In Chinese).

23. Lin CH, Kuo KT, Chuang SS, Kuo SH, Chang JH, Chang KC, Hsu HC, Tien HF and Cheng AL: Comparison of the expression and prognostic significance of differentiation markers between diffuse large B-Cell lymphoma of central nervous system origin and peripheral nodal origin. Clin Cancer Res 12: 1152-1156, 2006.

24. Camilleri-Broët S, Crinière E, Broët P, Delwail V, Mokhtari K, Moreau A, Kujas M, Raphaël M, Iraqi W, Sautès-Fridman C, et al: A uniform activated B-cell-like immunophenotype might explain the poor prognosis of primary central nervous system lymphomas: Analysis of 83 cases. Blood 107: 190-196, 2006.

25. Patel B, Chacko G, Nair S, Anandan J, Chacko AG, Rajshekhar V and Turel M: Clinicopathological correlates of primary central nervous system lymphoma: Experience from a tertiary care center in South India. Neurol India 63: 77-82, 2015.

26. Mounier N, Briere J, Gisselbrecht C, Emile JF, Lederlin P, Sebban C, Berger F, Bosly A, Morel P, Tilly H, et al: Rituximab plus CHOP (R-CHOP) overcomes BCL-2-associated resistance to chemotherapy in elderly patients with diffuse large B-cell lymphoma (DLBCL). Blood 101: 4279-4284, 2003.

27. Oken MM, Creech RH, Tormey DC, Horton J, Davis TE, McFadden ET and Carbone PP: Toxicity and response criteria of the Eastern Cooperative Oncology Group. Am J Clin Oncol 5: 649-655, 1982.

28. Patel B, Chacko G, Nair S, Anandan J, Chacko AG, Rajshekhar V and Turel M: Clinicopathological correlates of primary central nervous system lymphoma: Experience from a tertiary care center in South India. Neurol India 63: 77-82, 2015. 
29. Braaten KM, Betensky RA, de Leval L, Okada Y, Hochberg FH, Louis DN, Harris NL and Batchelor TT: BCL-6 expression predicts improved survival in patients with primary central nervous system lymphoma. Clin Cancer Res 9: 1063-1069, 2003.

30. Kreher S, Jöhrens K, Strehlow F, Martus P, Borowiec K, Radke J, Heppner F, Roth P, Thiel E, Pietsch T, et al: Prognostic impact of B-cell lymphoma 6 in primary CNS lymphoma. Neuro Oncol 17: 1016-1021,2015.

31. Hashmi AA, Hussain ZF, Faridi N and Khurshid A: Distribution of Ki67 proliferative indices among WHO subtypes of non-Hodgkin's lymphoma: Association with other clinical parameters. Asian Pac J Cancer Prev 15: 8759-8763, 2014.

32. Gerdes J, Lemke H, Baisch H, Wacker HH, Schwab U and Stein H: Cell cycle analysis of a cell proliferation-associated human nuclear antigen defined by monoclonal antibody Ki67. J Immunol 133: 1710-1715, 1984.

33. Niikura $\mathrm{N}$, Iwamoto $\mathrm{T}$, Masuda $\mathrm{S}$, Kumaki $\mathrm{N}$, Xiaoyan $\mathrm{T}$, Shirane M, Mori K, Tsuda B, Okamura T, Saito Y, et al: Immunohistochemical Ki67 labeling index has similar proliferation predictive power to various gene signatures in breast cancer Cancer Sci 103: 1508-1512, 2012.

34. Jovanović MP, Jaković L, Bogdanović A, Marković O, Martinović VC and Mihaljević B: Poor outcome in patients with diffuse large B-cell lymphoma is associated with high percentage of bcl-2 and Ki 67-positive tumor cells. Vojnosanit Pregl 66: 738-743, 2009.

35. Miller TP, Grogan TM, Dahlberg S, Spier CM, Braziel RM, Banks PM, Foucar K, Kjeldsberg CR, Levy N, Nathwani BN, et al: Prognostic significance of the Ki-67-associated proliferative antigen in aggressive non-Hodgkin's lymphomas: A prospective Southwest Oncology Group trial. Blood 83: 1460-1466, 1994.

36. Broyde A, Boycov O, Strenov Y, Okon E, Shpilberg O and Bairey O: Role and prognositic significance of the Ki-67 index in non-Hodgkin's lymphoma. Am J Hematol 84: 338-343, 2009.

37. Dogan A, Bagdi E, Munson P and Isaacson PG: CD10 and BCL-6 expression in paraffin sections of normal lymphoid tissue and B-cell lymphomas. Am J Surg Pathol 24: 846-852, 2000.

38. Falini B and Mason DY: Proteins encoded by genes involved in chromosomal alterations in lymphoma and leukemia: Clinical value of their detection by immunocytochemistry. Blood 99 . 409-426, 2002.
39. Falini B, Fizzotti M, Pucciarini A, Bigerrna B, Marafioti T, Gambacorta M, Pacini R, Alunni C, Natali-Tanci L, Ugolini B, et al: A monoclonal antibody (MUM1p) detects expression of the MUM1/IRF4 protein in a subset of germinal center B cells, plasma cells, and activated T cells. Blood 95: 2084-2092, 2000.

40. Rosenwald A, Wright G, Chan WC, Connors JM, Campo E, Fisher RI, Gascoyne RD, Muller-Hermelink HK, Smeland EB, Giltnane JM, et al: The use of molecular profiling to predict survival after chemotherapy for diffuse large B-cell lymphoma. N Engl J Med 346: 1937-1947, 2002.

41. Hockenbery D, Nuñez G, Milliman C, Schreiber R and Korsmeyer SJ: Bcl-2 is an inner mitochondrial membrane protein that blocks programmed cell death. Nature 348: 334-336, 1990.

42. Goscoyne RD, Adomat SA, Krajewski S, Krajewska M, Horsman DE, Tolcher AW, O'Reilly SE, Hoskins P, Coldman AJ, Reed JC and Connors JM: Prognostic significance of BCL-2 protein expression and BCL-2 gene rearrangement in diffuse aggressive non-Hodgkin' s lymphoma. Blood 90: 244-251, 1997.

43. Mahmoud HM and EI-Sakhawy YN: Significance of Bcl-2 and Bcl-6 immunostaining in B-Non Hodgkin's lymphoma. Hematol Rep 3: e26, 2011.

44. Krogh-Jensen M, Johansen P and D'Amore F: Primary central nervous system lymphomas in immunocompetent individuals: Histology, Epstein-Barr virus genome, $\mathrm{Ki}-67$ proliferation index, p53 and bcl-2 gene expression. Leuk Lymphoma 30: 131-142, 1998.

45. Preusser M, Woehrer A, Koperek O, Rottenfusser A, Dieckmann K, Gatterbauer B, Roessler K, Slavc I, Jaeger U, Streubel B, et al: Primary central nervous system lymphoma: A clinicopathological study of 75 cases. Pathology 42: 547-552, 2010.

46. Cattoretti G, Chang CC, Cechova K, Zhang J, Ye BH, Falini B, Louie DC, Offit K, Chaganti RS and Dalla-Favera R: BCL-6 protein is expressed in germinal-center B cells. Blood 86: 45-53, 1995.

47. Falini B, Bigerna B, Pasqualucci L, Fizzotti M, Martelli MF, Pileri S, Pinto A, Carbone A, Venturi S, Pacini R, et al: Distinctive expression pattern of the BCL-6 protein in nodular lymphocyte predominance Hodgkin's disease. Blood 87: 465-471, 1996. 